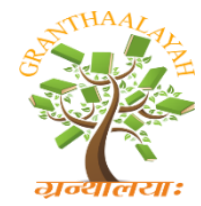

INTERNATIONAL JOURNAL OF RESEARCH GRANTHAALAYAH A knowledge Repository

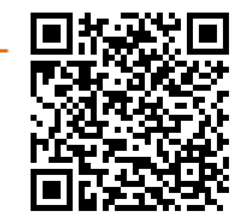

Management

\title{
PROGRESS OF FINANCIAL INCLUSION THROUGH FIPS OF SCHEDULED COMMERCIAL BANKS
}

\author{
Mohana Krishna Irrinki ${ }^{* 1}$, Kuberudu Burlakanti ${ }^{2}$ \\ ${ }^{* 1}$ Research Scholar, JNTUK, Kakinada, Andhra Pradesh, India \\ ${ }^{2}$ Professor \& HoD, Department of MBA, AUMSN PG Center, Kakinada, Andhra Pradesh, India
}

\begin{abstract}
All the stakeholders of the economy had identified the need and importance of financial inclusion in the overall development of any country. Banking sector plays a very vital role in the success of financial inclusion. Government and RBI had formulated various programs, schemes and financial services for the financial betterment of the low income groups. Various initiations were taken in implementing financial inclusion and banks were asked to set self-regulated targets through financial inclusion plans through which the unbanked villages across the country were assigned to various banks and these banks were asked to bring all the unbanked segments into the banking fold. The paper aims at the evaluation of financial inclusion through the various parameters considered for the growth of financial inclusion. The banks through the efforts of their branches and Business Correspondents have seen the continuous growth in opening the bank accounts, issue of Kisan Credit Cards \& General Credit Cards and the volume and value of transactions in the bank accounts. Financial Inclusion Plans of the banks are helping a lot in moving towards inclusive growth.
\end{abstract}

Keywords: Financial Inclusion; Financial Inclusion Plan; Reserve Bank of India; Financial Literacy.

Cite This Article: Mohana Krishna Irrinki, and Kuberudu Burlakanti. (2017). "PROGRESS OF FINANCIAL INCLUSION THROUGH FIPs OF SCHEDULED COMMERCIAL BANKS." International Journal of Research - Granthaalayah, 5(8), 146-157. https://doi.org/10.29121/granthaalayah.v5.i8.2017.2202.

\section{Introduction}

There has been tremendous growth of the economy over the past years and the same is not getting reflected in the lives of the poor. There are evidences that the fruits of the economic development are not evenly distributed among the people and this is leading to poverty and disparities in income. To have equal development of the people of the country there should be an equal opportunities for access and usage of the various financial services. Most of the countries have identified that the financial inclusion is the mantra to have inclusive growth which can be a true indicator of the economic development. It is viewed that financial exclusion is most among 
the low income groups and these are also socially excluded. To overcome these disparities financial inclusion needs to be implemented and executed effectively to achieve inclusive growth. The government is giving top priority towards the achievement of this which is evident of its policy measures.

The United Nations defines it as "a financial sector that provides access to credit for all "bankable" people and firms and to savings and payments services for everyone. Inclusive Finance does not require that everyone who is eligible use each of the services, but they should be able to choose use them if desired.

Financial inclusion is the process of providing access to various financial services and products on timely availability and adequate provision of credit when needed by the vulnerable groups at an affordable cost. The phenomenon of financial inclusion broadens the resource base of the financial system by developing the habit of savings among rural population and which plays a vital role in the economic development of the country. Financial inclusion helps in connecting the households irrespective of their area of residence to a well-functioning financial system. This enables to have easy access to basic banking services to save their savings, availability to credit through appropriately designed loans for poor \& low income households and small entrepreneurs at a lower rate of interest and availability of other basic financial products like insurance, pension etc.

\section{Objectives of the Study}

- To study the status of financial inclusion in India.

- To study the progress of financial inclusion over the years through Financial Inclusion Plans.

The study considers the data from March 2010 to March 2016. The various parameters are considered through which the progress of financial inclusion is estimated and analyzed. The data is collected from the websites of RBI, NABARD and other government agencies.

\section{Review of Literature}

Prahalad C K (2004) strongly argued that "Serving the Bottom of the Pyramid (BOP) consumers will demand innovations in technology, products and services, and business strategies". More importantly, it will require large firms to work collaboratively with civil society organizations and local governments. Market development at the BOP will also create millions of new entrepreneurs at the grass roots level from women working as distributors and entrepreneurs to village-level micro enterprises. These micro enterprises will be an integral part of the market-based ecosystem. It will require organizational and governance innovations as well as prosperity. It can be a source of innovations. When the poor are converted into consumers, they will go for more than access to product and service, the poor themselves are willing to experiment, learn, and change. The interconnectedness of the approach to economic development and social transformation is visualized. Serving the BOP consumers improved domestic macroeconomic conditions bode well for domestic revenue outlook. 
Reena Agrawal (2011) indicated that financial exclusion is a serious concern among SC, ST, $\mathrm{OBC}$ and women households as well as small businesses, mainly located in semi-urban and rural areas. The main Consequences of financial exclusion being financially excluded the absence of access to bank accounts and other saving opportunities result in lack of savings, low investments and lack of financial planning, then it becomes difficult in gaining access to credit getting credit from informal sources at exorbitant rates results in increased unemployment due to lack of self employment opportunities as well as higher incidence of crime etc. Therefore, small business may suffer due to loss of access to middle class, and higher-income consumers, higher cash handling costs, delays in remittances of money, lots of reliance on private money lenders for small credits. He concluded that financial exclusion not only widens the 'Rich-Poor divide', it also leads to 'Social Exclusion'.

Puneet Bhushan \&Yajulu Medury (2013) Suggest that overall financial literacy level of respondents is not very high. Financial literacy level gets affected by gender, education, income, nature of employment and place of work whereas it is found that the people who are government employee has less level in comparison to the privet employee, geographical region do not affect the level of financial literacy. The level of financial literacy among the working young in urban India is similar to the levels that prevail among comparable groups in other countries i.e. the influence of several socio-demographic variables like influence of family income and gender on various dimensions of financial literacy is similar as recorded in other studies in Indian context.

\section{Financial Inclusion in India}

Reserve Bank of India has defined Financial inclusion as the process of ensuring access to appropriate financial products and services needed by vulnerable groups such as weaker sections and low income groups at an affordable cost in a fair and transparent manner by mainstream Institutional players.

Only $50 \%$ of India's population doesn't have access to the basic banking services and $75 \%$ of the population is not covered by any form of insurance. India has identified financial inclusion as one of the important national objectives and to achieve this, the Government of India and the Reserve Bank of India are making concerted efforts. Some of the efforts made by the Government and RBI include - nationalization of banks, increasing the branch network of banks, co-operatives and regional rural banks, introduction of mandated priority sector lending, formation of SHGs, lead bank scheme, allowing BCs/BFs to be appointed by banks to provide door step delivery of basic banking services, zero balance Basic Saving Bank Deposit (BSBD) accounts, etc. The objective of these initiatives is to connect the large sections of the financially excluded population. Conducive regulatory environment was created by RBI and provided institutional support for banks in accelerating their financial inclusion efforts to achieve the target.

Due to lack of access to formal financial institutions the financially excluded sections of the society are having limited options in creating assets or to save for their old age. In view of this the financially excluded segments are forced to approach informal sources of finance, which often charge $60 \%$ to $100 \%$ in annual interest payments. Exposure to such high rates of interest and the inability to clear the loans is leading them to be trapped in debt. The new agenda for 
financial inclusion seeks to address both of these long-standing concerns for India. There has been a paradigm shift in the approach of financial inclusion from an emphasis on credit to a more comprehensive approach toward access to financial services, especially opening bank accounts and offering basic financial products. This shift has been driven by replacing product subsidies with cash transfers who requires the beneficiary to have bank accounts for availing these transfers.

\section{Financial Inclusion Plans}

To achieve financial inclusion, RBI has designed Financial Inclusion Plan through which the banks have to provide basic banking services to the people of the unbanked villages. It is perused in two phases of three years each spanning from 2010-2013 and 2013-2016. As part of financial inclusion plan the targets in establishing bank branches in rural areas, recruiting business correspondents, covering the unbanked villages with more than 2000 population and later the unbanked villages with less than 2000 population, opening no-frill accounts, issuing Kisan Credit Cards, General Credit Cards, transactions through Business Correspondents using Information and Communication Technology and other financial services and products aimed to cater to the needs of the financially excluded segments of the society,

\section{PHASE I}

First phase is from 2010-2013 and during this 74,414 unbanked villages with population more than 2,000 were identified and allotted to various banks through SLBCs (State Level Bank Committees) for coverage through bank branches, Business Correspondents or other modes such as ATMs and satellite branches, etc.

\section{Achievements under Phase I of FIP}

With the completion of the first phase, nearly 74,000 unbanked villages with population more than 2,000 were provided with a banking outlet comprising of 2,493 branches, 69,589 Business Correspondents and 2,332 through other modes. Despite the creation of the large banking network and through which most of the households are brought under the banking sector by opening basic bank accounts, the real objective of financial inclusion couldn't be achieved. To bring uniformity in the reporting the banks were directed to disaggregate their financial inclusion plans and concentrate and penetrate at the branch level.

\section{PHASE II}

The second phase of financial inclusion plan is from 2013-2016 and during this phase the remaining unbanked villages which are close to 4,90,000 were identified and most of them have population of less than 2000 people. These villages are assigned to various banks for opening banking outlets by March 2016. In $n$ this phase the emphasis is on opening the bank accounts and also making these accounts active and operative. The focus is on the volume of transactions being done in the newly opened accounts. The RBI is closely monitoring the progress of financial inclusion plans and the contribution of the banks in this process. 
There is improvement in the progress of achieving financial inclusion in the second phase when compared to that of the first phase.

Progress of Financial Inclusion over the years

\begin{tabular}{|c|c|c|c|c|c|c|c|c|}
\hline $\begin{array}{c}\text { Sn } \\
\text { o }\end{array}$ & $\begin{array}{c}\text { Variable } \\
\text { Component }\end{array}$ & $\begin{array}{l}\text { Mar } \\
2010\end{array}$ & $\begin{array}{l}\text { Mar } \\
2011\end{array}$ & $\begin{array}{l}\text { Mar } \\
2012\end{array}$ & $\begin{array}{l}\text { Mar } \\
2013\end{array}$ & $\begin{array}{l}\text { Mar } \\
2014\end{array}$ & $\begin{array}{l}\text { Mar } \\
2015\end{array}$ & $\begin{array}{l}\text { Mar } \\
2016\end{array}$ \\
\hline 1 & $\begin{array}{l}\text { Banking Outlets in } \\
\text { Villages - Branches }\end{array}$ & 33378 & 34811 & 37471 & 40837 & 46126 & 49571 & 51830 \\
\hline 2 & $\begin{array}{l}\text { Banking Outlets in } \\
\text { Villages - Branchless } \\
\text { Mode }\end{array}$ & 34316 & 81397 & 144282 & 227617 & 337678 & 504142 & 534477 \\
\hline 3 & $\begin{array}{l}\text { Banking Outlets in } \\
\text { Villages - Total }\end{array}$ & 67694 & 116208 & 181753 & 268454 & 383804 & 553713 & 586307 \\
\hline 4 & $\begin{array}{l}\text { Urban Locations } \\
\text { covered through BCs }\end{array}$ & 447 & 3771 & 5891 & 27143 & 60730 & 96847 & 102552 \\
\hline 5 & $\begin{array}{l}\text { Basic Savings Bank } \\
\text { Deposit Account } \\
\text { (BSBDA) through } \\
\text { branches (No. in } \\
\text { millions) }\end{array}$ & 60 & 73 & 81 & 101 & 126 & 210 & 238 \\
\hline 6 & $\begin{array}{l}\text { Basic Savings Bank } \\
\text { Deposit Account } \\
\text { (BSBDA) through } \\
\text { branches (Amt. in } \\
\text { Rs. billion) }\end{array}$ & 44 & 58 & 110 & 165 & 273 & 365 & 474 \\
\hline 7 & $\begin{array}{l}\text { Basic Savings Bank } \\
\text { Deposit Account } \\
\text { (BSBDA) through } \\
\text { BCs (No. in } \\
\text { millions) }\end{array}$ & 13 & 32 & 57 & 81 & 117 & 188 & 231 \\
\hline 8 & $\begin{array}{l}\text { Basic Savings Bank } \\
\text { Deposit Account } \\
\text { (BSBDA) through } \\
\text { BCs (Amt. in Rs. } \\
\text { billion) }\end{array}$ & 11 & 18 & 11 & 18 & 39 & 75 & 164 \\
\hline 9 & $\begin{array}{l}\text { BSBDA Total (in } \\
\text { millions) }\end{array}$ & 73 & 105 & 139 & 182 & 243 & 398 & 469 \\
\hline 10 & $\begin{array}{l}\text { BSBDA Total (Amt. } \\
\text { in Rs. billion) }\end{array}$ & 55 & 76 & 120 & 183 & 312 & 440 & 638 \\
\hline 11 & $\begin{array}{l}\text { OD facility availed in } \\
\text { Basic Savings Bank } \\
\text { Deposit Account (No. } \\
\text { in millions) }\end{array}$ & 0.2 & 1 & 3 & 4 & 6 & 8 & 9 \\
\hline 12 & $\begin{array}{l}\text { OD facility availed in } \\
\text { Basic Savings Bank } \\
\text { Deposit Account } \\
\text { (Amt. in Rs. billion) }\end{array}$ & 0.1 & 0.3 & 1 & 2 & 16 & 20 & 29 \\
\hline 13 & $\begin{array}{l}\text { KCCs-Total (No. in } \\
\text { millions) }\end{array}$ & 24 & 27 & 30 & 34 & 40 & 43 & 47 \\
\hline
\end{tabular}




\begin{tabular}{|c|l|c|c|c|c|c|c|c|}
\hline 14 & $\begin{array}{l}\text { KCCs-Total (Amt. in } \\
\text { Rs. billion) }\end{array}$ & 1240 & 1600 & 2068 & 2,623 & 3684 & 4,382 & 5,131 \\
\hline 15 & $\begin{array}{l}\text { GCC-Total (No. in } \\
\text { millions) }\end{array}$ & 1 & 2 & 2 & 4 & 7 & 9 & 11 \\
\hline 16 & $\begin{array}{l}\text { GCC-Total (Amt. in } \\
\text { Rs. billion) }\end{array}$ & 35 & 35 & 42 & 76 & 1,097 & 1,302 & 1,493 \\
\hline 17 & $\begin{array}{l}\text { ICT A/Cs-BC Total } \\
\text { Transactions (No. in } \\
\text { million) during the } \\
\text { year }\end{array}$ & 27 & 54 & 156 & 250 & 329 & 477 & 827 \\
\hline 18 & $\begin{array}{l}\text { ICT A/Cs-BC Total } \\
\text { Transactions (Amt. } \\
\text { in Rs. billion) during } \\
\text { the year }\end{array}$ & 7 & 58 & 234 & 524 & 860 & 1687 \\
\hline
\end{tabular}

*Data collected from RBI websites

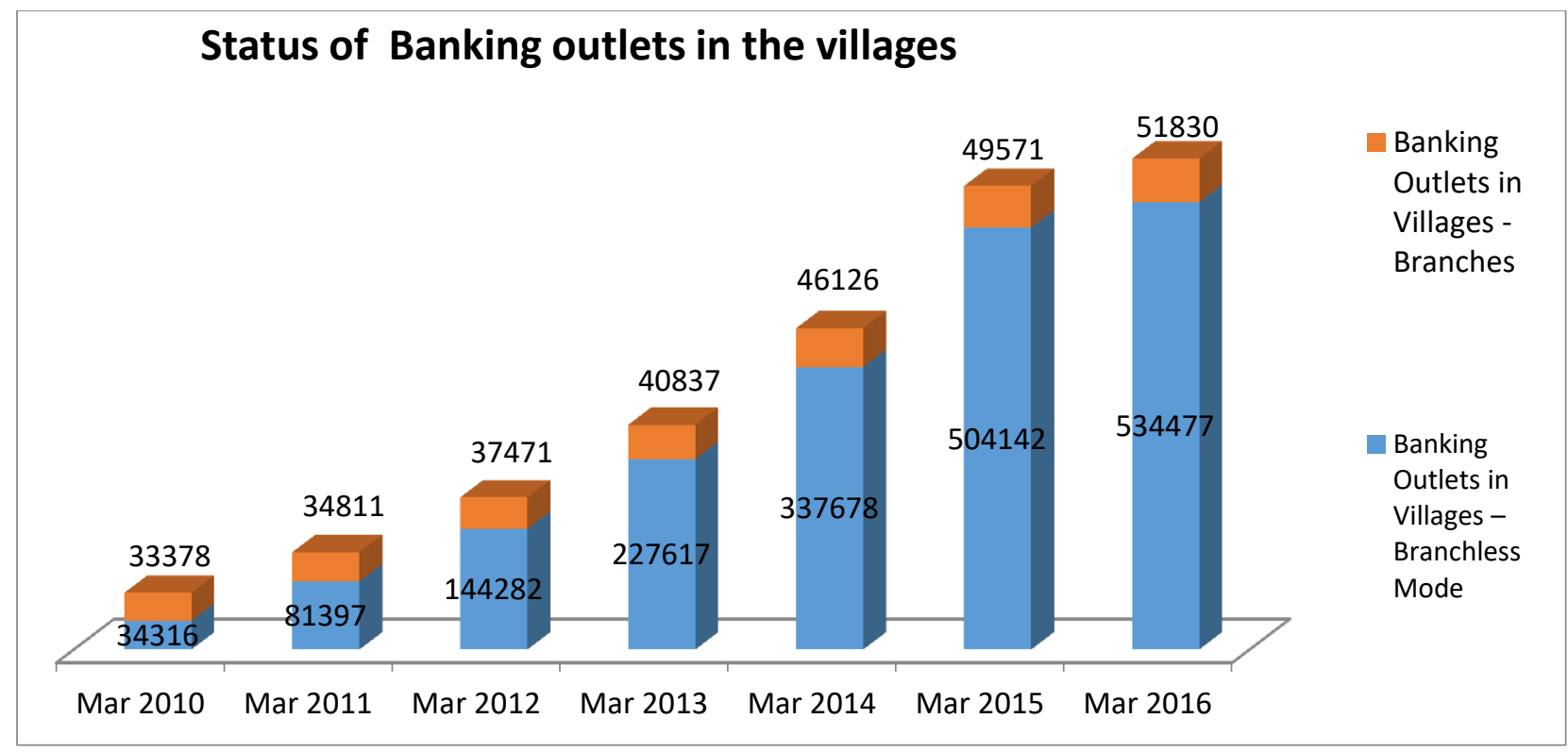

Figure 1: Progress of banking outlets in the villages

Figure 1 shows the progress of banking outlets in the villages over the period from March 2010 to March 2016. From the data it is evident that there is continuous progress of branchless mode of banking outlets in the villages. In March 2010 the ratio of branch outlets to branchless mode of outlets are in the ratio of $49.31 \%$ and $50.69 \%$ respectively and the same in March 2016 are $8.84 \%$ to $91.16 \%$. This shows the rapid growth of branchless mode of banking outlets to cater to the needs of the rural population. Considering the total banking outlets in the villages there is continuous growth rate of $71.67 \%, 56.4 \%, 47.7 \%, 42.97 \%, 44.27 \%$ and $5.89 \%$ respectively from March 2011 to March 2016. 


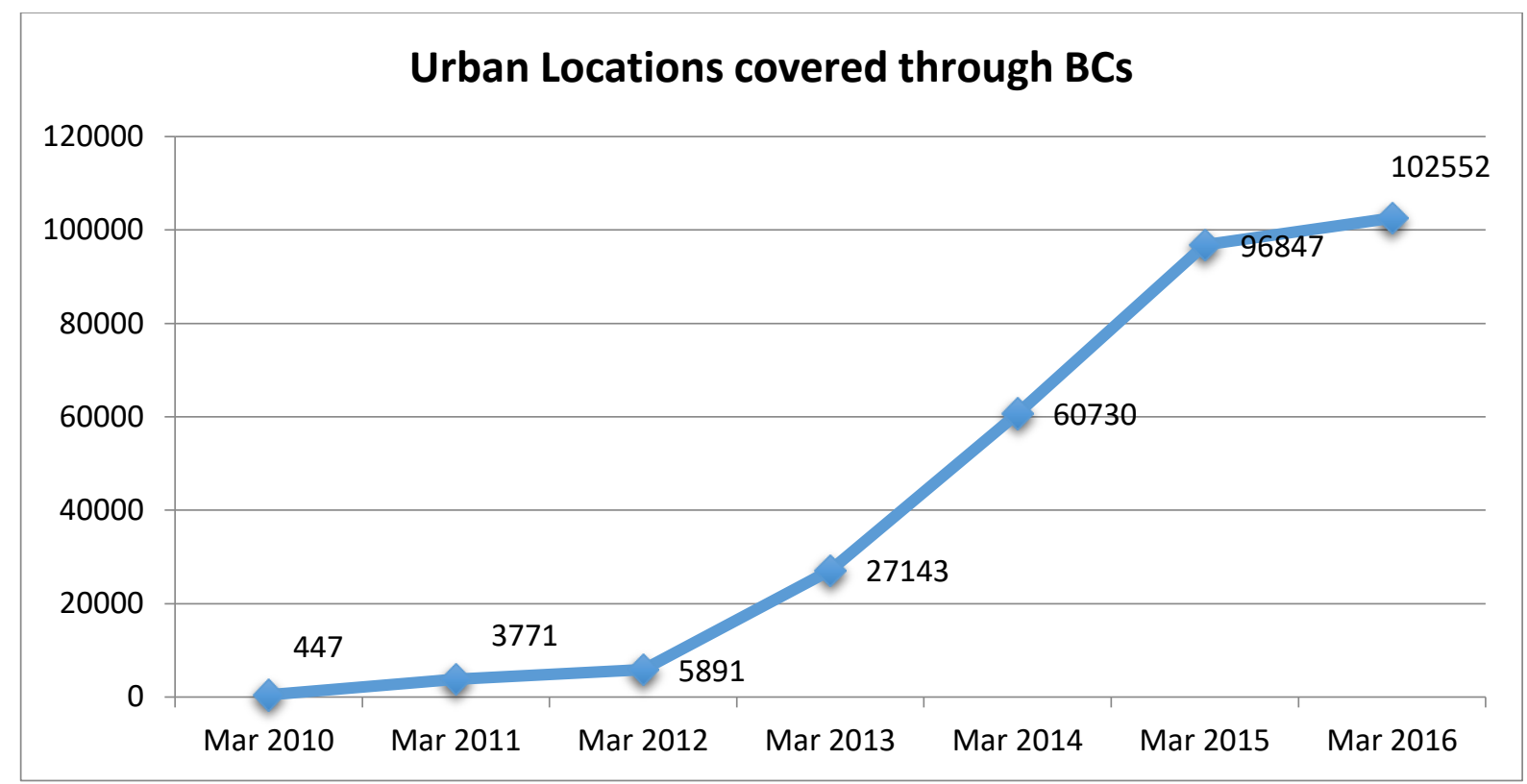

Figure 2: Urban locations covered by Business Correspondents

Figure 2 shows the growth of urban locations covered by Business Correspondents over the years. The number has moved from 447 in March 2010 to 102552 in March 2016. There is tremendous growth rate of the locations covered over the years. The growth rate is $743.62 \%$, $56.22 \%, 360.75 \%, 123.74 \%, 59.47 \%$ and 5.89\% respectively from March 2011 to March 2016. This mainly attributed to the hiring of Business Correspondents by the banks in a large scale.

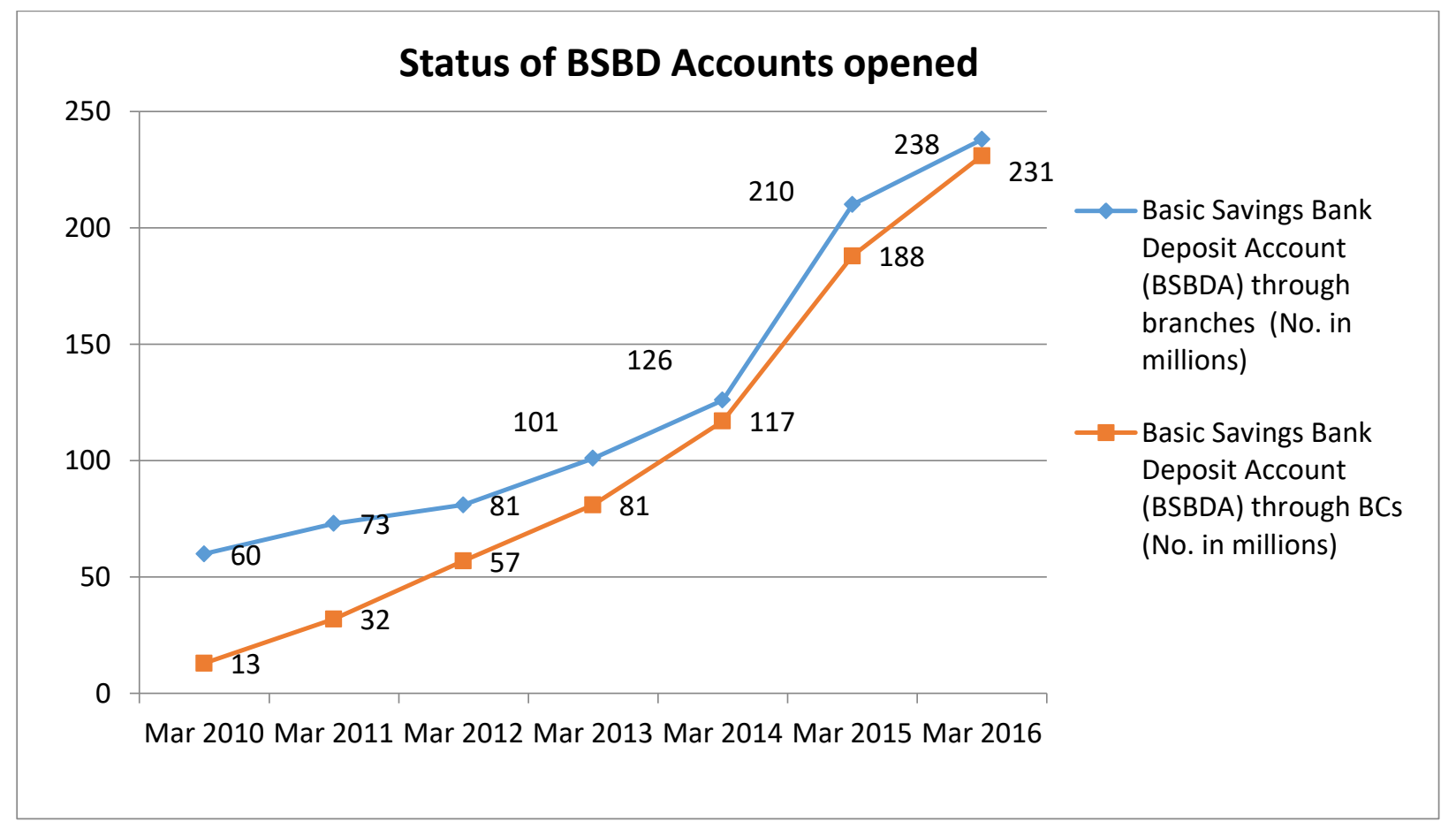

Figure 3: Progress of Basic Savings Bank Deposit Accounts opened 
Figure 3 shows the Basic Savings Bank Deposit (BSBD) Accounts opened by the branches and Business correspondents over the years under consideration. These accounts were earlier called as no-frill accounts which were opened either with zero balance or marginal amounts. In the initial years the accounts were opened through banks and from 2013 there is equal number of accounts opened both at the branches and through business correspondents. In March 2010 the BSBD accounts opened through branches are $82.19 \%$ and through business correspondents are $17.81 \%$ and by March 2016 the ratios are 50.75\% and 49.25\% respectively. The rapid increase in the number of accounts opened is due to the recruitment of business correspondents by the banks for achieving the targets of financial inclusion plans. By March 2016 more than 469 million accounts were opened in the unbanked villages.

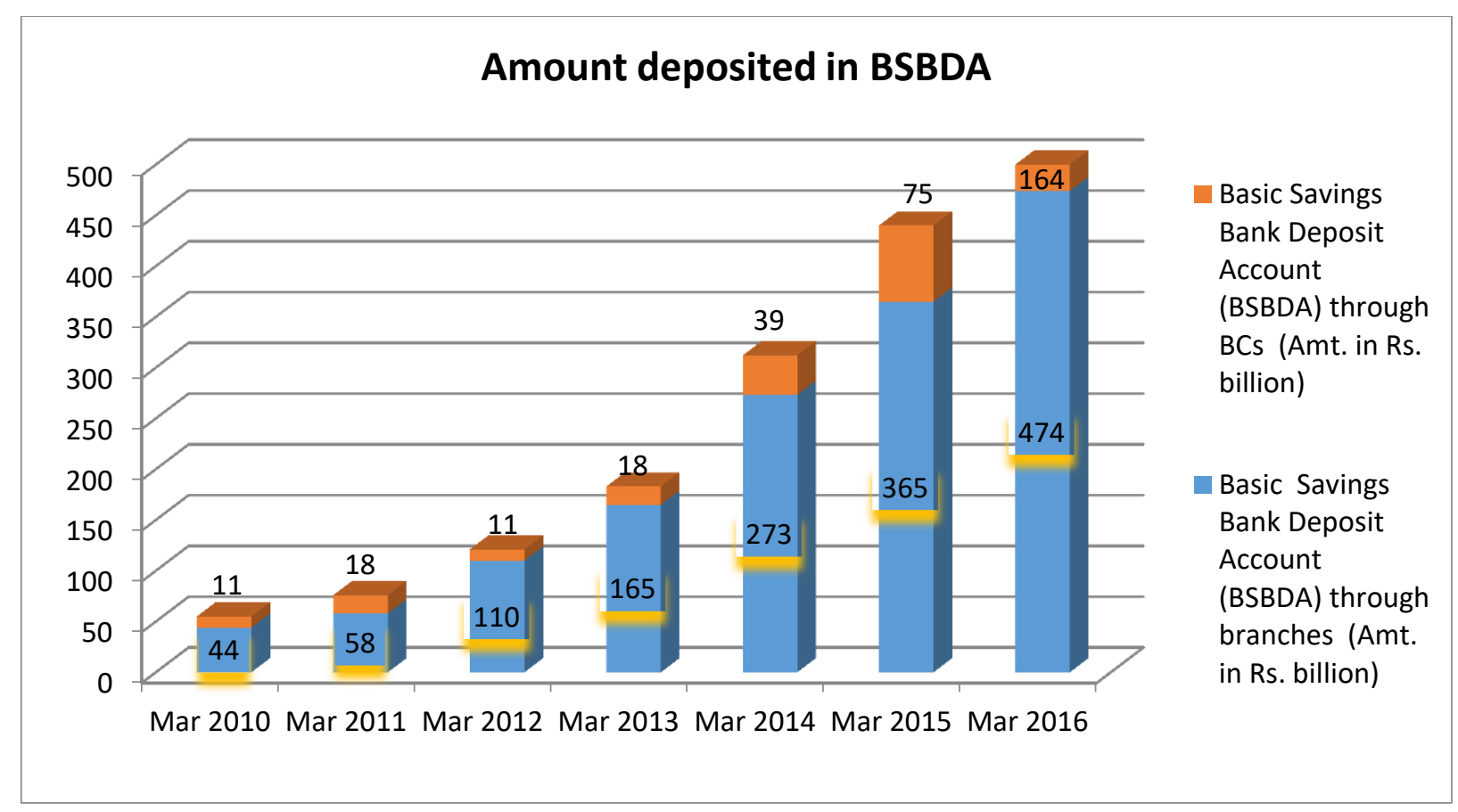

Figure 4: Amount collected through BSBD Accounts

Figure 4 shows the amounts deposited in the BSBD Accounts opened in the unbanked villages. There is a continuous growth in the amounts deposited in the accounts opened which imply that certain transactions are being performed in the accounts rather than keeping them dormant. From the data it is evident that the accounts are opened aggressively both by the branches and business correspondents but the transactions are performed more by the branches rather than through business correspondents. The amounts deposited in these accounts have increased from 55 billion in March 2010 to 638 billion in March 2016. The ratio of amounts between branches and business correspondents in March 2010 are 80\% and 20\% respectively and for the year March 2016 it is $74.29 \%$ and $25.71 \%$ respectively. From this it can be inferred that though the amounts are getting increased the contribution from the business correspondents is not in the same ratio when compared to that of opening the accounts. 


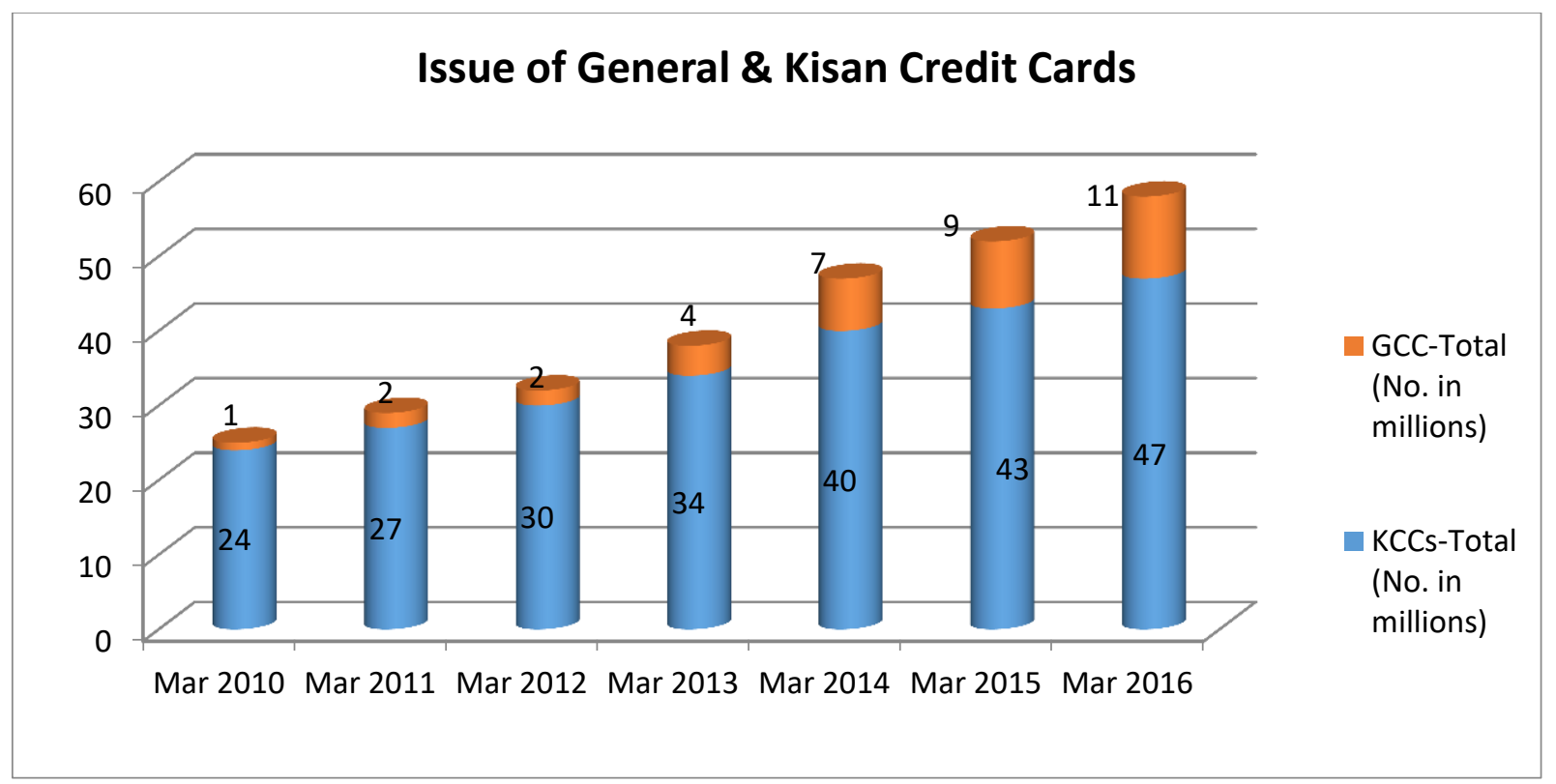

Figure 5: Issue of General and Kisan Credit Cards

Figure 5 shows the data pertaining to the issue of Kisan and General Credit Cards to the accountholders of the unbanked villages over the years. There is a continuous growth in the number of cards issued starting from 1 million of General Credit cards in 2010 to 11 million in March 2016. Similarly Kisan Credit Cards are issued to 24 million in March 2010 and 47 million in March 2016. The Kisan Credit Cards has registered growth rates of 12.5\%, 11.11\%, 13.33\%, $17.35 \%, 7.77 \%$ and 9.3\% respectively from March 2011 to March 2016. Similarly the General Credit Cards had registered growth rates of $100 \%, 0 \%, 100 \%, 85 \%, 24.32 \%$ and $19.57 \%$ respectively from March 2011 to March 2016.

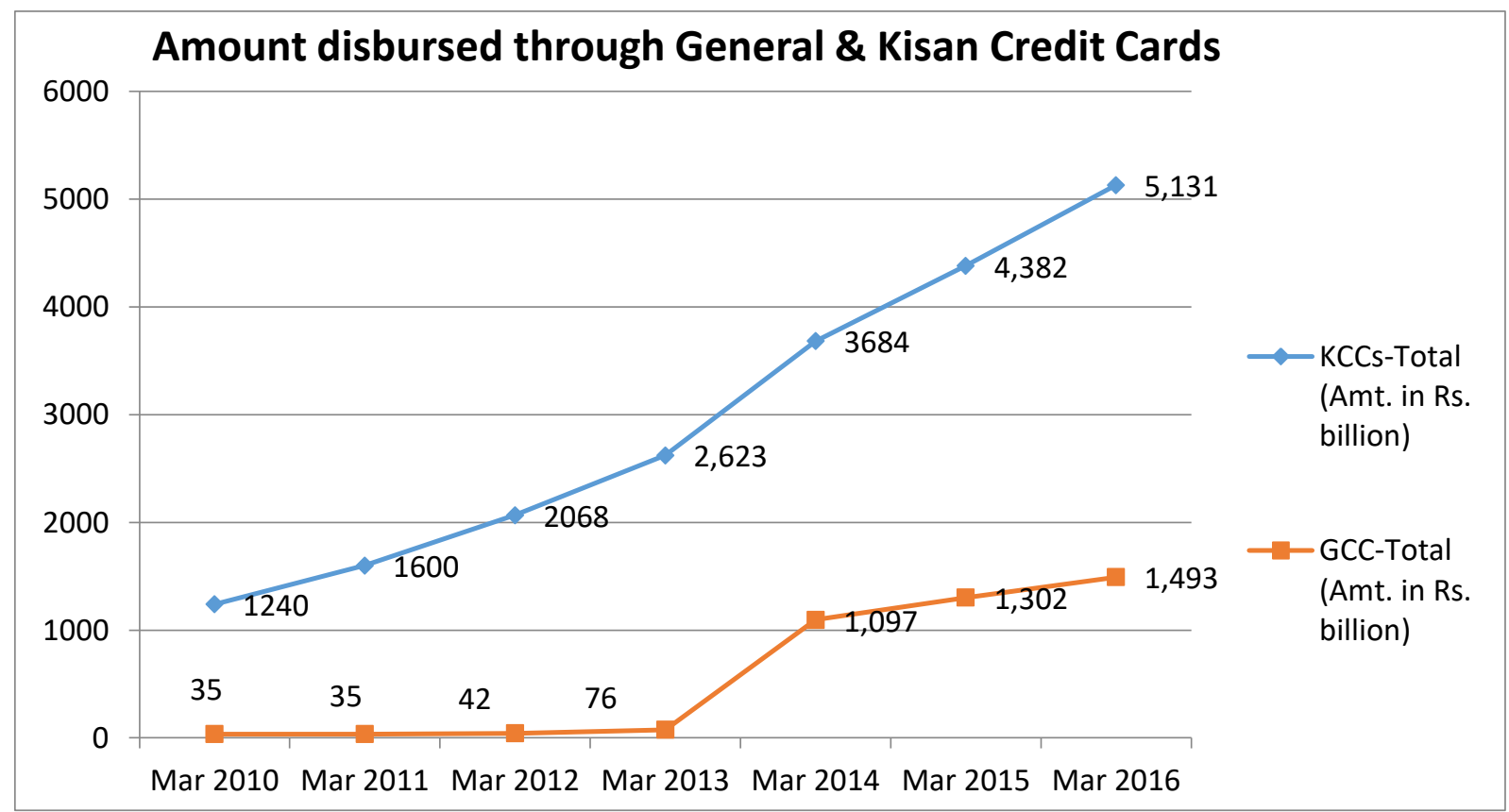

Figure 6: 
Figure 6 shows the amounts disbursed through Kisan Credit Cards and General Credit Cards over the years. Huge amounts were disbursed through Kisan Credit Cards. Out of the 47 million KCC issued an amount of Rs5131 billions were disbursed. The disbursement of amounts saw a continuous growth over the years. The amount has risen from 1240 billion in March 2010 to 5131 billion in March 2016. The growth rates are 29.03\%, 29.25\%, 26.84\%, 40.45\%, 18.95\% and $17.08 \%$ respectively from March 2011 to March 2016.

Similarly there is continuous growth in the amounts disbursed under General Credit Cards. Out of the 11 million GCC issued an amount of Rs 1493 billion were disbursed. The disbursement of amounts saw a continuous growth over the years. The amount has risen from Rs. 35 billion in March 2010 to Rs. 1493 billion in March 2016. The growth rates are 20\%, 80.95\%, 1343.29\%, $18.66 \%$ and $14.7 \%$ respectively from March 2012 to March 2016. High variation was observed March 2014 which was the year where the second phase of FIP was initiated and new guidelines were issued for issue of General Credit Cards.

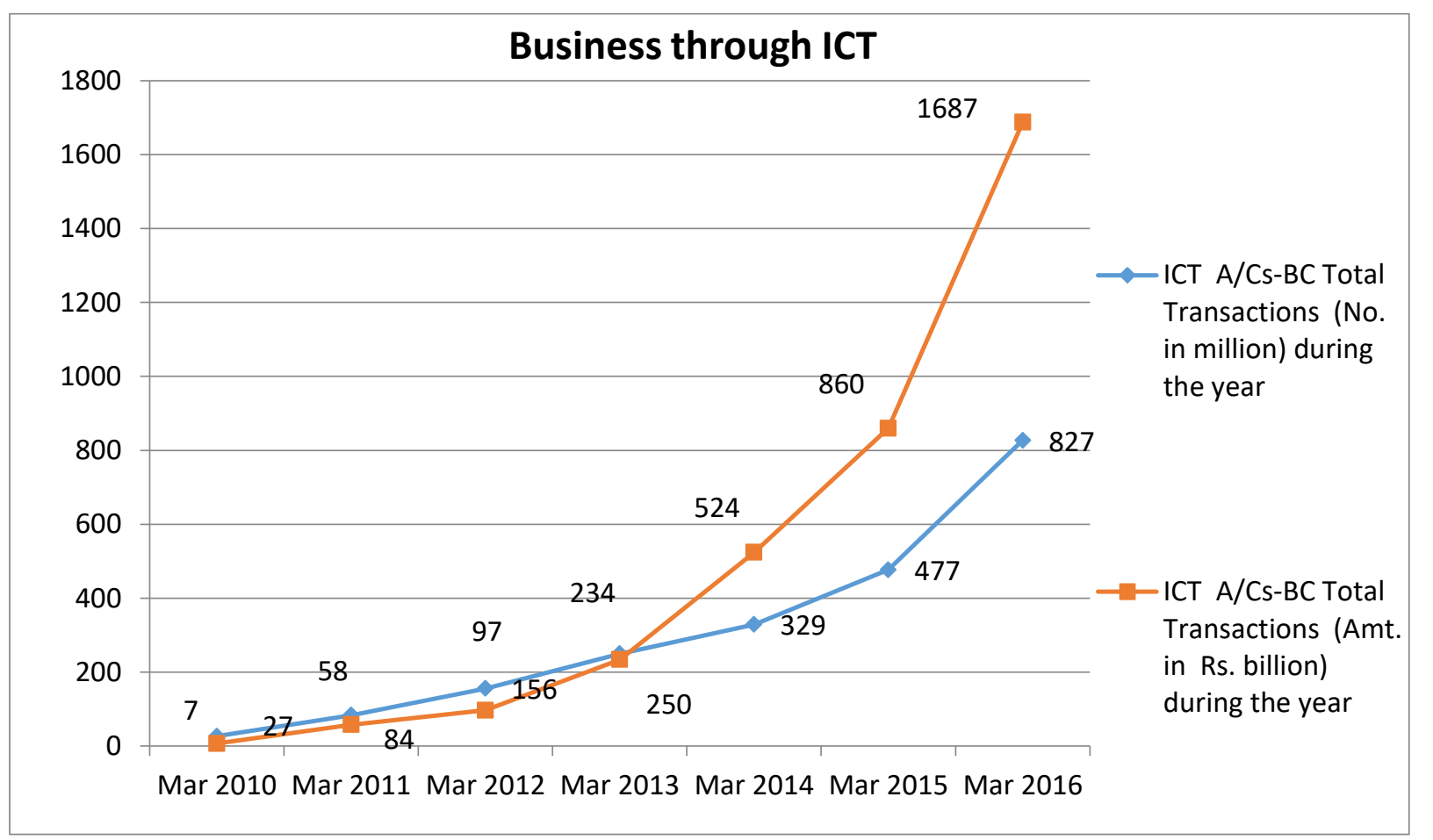

Figure 7: Transactions by BCs using Information and Communication Technology

Figure 7 shows the volume and value of transactions done by Business Correspondents using Information and Communication Technology. Both the parameters are showing consistent raise in their values. In March 2010 the number of transactions was 27 million and by March 2016 it is 827 million. There is a growth rate of $211.11 \%, 85.71 \%, 60.26 \%, 31.44 \%, 45.16 \%$ and $73.38 \%$ from March 2011 to March 2016. Similarly the value of transactions done by Business Correspondents using Information and Communication Technology was at Rs 7 billion in March 2010 and Rs 1687 billion in March 2016. There is growth rate of 728.57\%, 67.24\%, 141.24\%, $124.1 \%$, 63.96\% and 96.21\% respectively from March 2011 to March 2016. From the data it can be presumed that the Business Correspondents are performing well and the volumes and values are being improved year upon year. 


\section{Steps to be taken for increase in Financial Inclusion}

- Financial Literacy: The need of financial literacy and its relevance for the success of financial inclusion have been identified by the policymakers, bankers, practitioners, researchers and academics. Financial Literacy and Financial Inclusion are vital for the financial stability of the country. A lot of unique financial literacy programs have been developed and executed by concerned institutions. Programs were designed with specific reference to financial products, inculcating saving habit among target group, customer protection, business management etc. Some programs were general and dealt with money management skills, advocating healthy financial practices etc. If the people are financial literates then they can identify and access the various financial services and products provided for their financial betterment. This accelerates the financial inclusion process.

- Introduction of Various benefit schemes: Government had introduced various social security schemes with an objective of broadening financial inclusion in India thereby enabling the financial services such as banking, insurance, pension etc are available to the low \& middle class sections of the society at an affordable cost and make them financially secured. Some of the schemes are Prandhan Mantri Suraksha Bima Yojana, Pradhan Mantri Jeevan Jyoti Bima Yojana, Atal Pension Yojana, Sukanya Samriddhi Yojana, Jeevan Suraksha Bandhan Yojana, Pradhan Mantri Jan Dhan Yojana.

- Direct Benefit Transfer: This is the program rolled out to transfer the subsidies directly into the accounts of the beneficiaries rather than giving it in cash. Banks were asked to ensure that all the accounts opened by them are seeded with Aadhar numbers which enables them towards the implementation of Electronic Benefit Transfer. This is started in 2013 in few districts and later spread across the nation. This had helped the government to save huge amounts and also forced the citizens to make use of the bank accounts opened for them.

\section{Conclusion}

There should a coordinated approach among the Government, Banks and other financial institutions towards the march in bringing the unbanked into the formal financial sector. Banks and other financial institutions should view opening of accounts and transactions by these financially excluded as a long term business opportunity rather than as an obligation by the regulatory authorities. The financial institutions should develop the products and services which can cater to the needs of the financially excluded people. Though there are various services available there is need to educate the people about the availability of these services to them which can be accomplished with the help of financial literacy camps. The progress of financial inclusion is good through the scheduled commercial banks with the help of financial inclusion plans which are self-set targets. There is continuous improvement in the path of financial inclusion through the various parameters considered for the progress. The business correspondents' model is also proving to be emerging and yielding better results. There is an increase in the banking outlets in these unbanked villages from 67694 in 2010 to 586307 in March 2016. Similarly the Basic Savings Bank Deposit accounts had increased from 73 million in March 2010 to 469 million in March 2016. The amount deposited in these accounts had risen from Rs 55 billion in March 2010 to Rs. 638 billion in March 2016. For 47 million Kisan Credit Cards an amount of Rs 5131 billion was disbursed and similarly for 11 million General Credit Cards an amount of Rs 1493 were disbursed in March 2016. Even the business correspondents 
are making using of the technology and making transactions which is amounting to Rs 1687 billion for 827 million transactions during the year 2016. The emphasis should be on the available services, providing awareness about the products and then protecting the customer interest. There is need to conduct financial literacy camps in the rural areas on a continuous basis which inturn helps in spiking the economic development of the country.

\section{References}

[1] Prahlad, The Fortune at the Bottom of the Pyramid, published by csrwire, 2004, http://www.csrwire.com/pdf/Prahalad-excerpt-001-022.pdf

[2] Reena Agrawal, 100\% Financial Inclusion: A Challenging Task Ahead present at Conference on Global Competition \& Competitiveness of Indian Corporate, IIM. Lucknow, 2011, p.p. 276-279

[3] Bhushan P, Et Al. Financial Literacy and Its Determinants (2013), Ijebea Pp. 155-160

[4] Pal Rama \& Rupayan Pal, 2012, "Income related inequality in financial inclusion and role of banks: Evidence on financial exclusion in India," Indira Gandhi Institute of Development Research, Mumbai Working Papers 2012-013.

[5] Reserve Bank of India - "Annual Reports and 'Report on Trend and Progress of Banking in India", various issues.

[6] Sarkar A N (2013), "Financial Inclusion: Fostering Sustainable Economic Growth in India", The Banker, Vol.VIII, No.4, pp.44-53.

[7] Radhika Dixit and M. Ghosh (2013) "Financial Inclusion for Inclusive Growth of India - A Study", International Journal of Business Management \& Research, Vol.3, Issue 1

[8] Paramjeet Kaur (2014), "A Study on Financial Inclusion - role of Indian banks in implementing a scalable and sustainable financial inclusion strategy", International Journal of Management (IJM).

[9] www.iibf.org.in/scripts/iib_financeinclusion.asp.

[10] www.rbi.org.in > Speeches

*Corresponding author.

E-mail address: kietmohan@ gmail.com 